WSRC-TR-2002-00450

Keywords: WASING, SLUDGE, TANK 7, OXALATE

Retention: Permanent

\title{
WASHING DEMONSTRATION USING NONRADIOACTIVE SIMULATED TANK 7 SLUDGE-SLURRY
}

J. M. Pareizs

Publication Date: November 7, 2002

Westinghouse Savannah River Company

Savannah River Site

Aiken, SC 29808

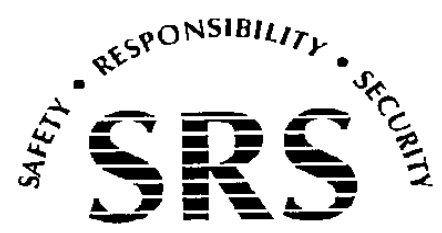

PREPARED FOR THE U.S. DEPARTMENT OF ENERGY UNDER CONTRACT NO. DE-AC09-96SR18500 
This document was prepared in conjunction with work accomplished under Contract No. DE-AC09-96SR18500 with the U. S. Department of Energy.

\section{DISCLAIMER}

This report was prepared as an account of work sponsored by an agency of the United States Government. Neither the United States Government nor any agency thereof, nor any of their employees, makes any warranty, express or implied, or assumes any legal liability or responsibility for the accuracy, completeness, or usefulness of any information, apparatus, product or process disclosed, or represents that its use would not infringe privately owned rights. Reference herein to any specific commercial product, process or service by trade name, trademark, manufacturer, or otherwise does not necessarily constitute or imply its endorsement, recommendation, or favoring by the United States Government or any agency thereof. The views and opinions of authors expressed herein do not necessarily state or reflect those of the United States Government or any agency thereof.

This report has been reproduced directly from the best available copy.

Available for sale to the public, in paper, from: U.S. Department of Commerce, National Technical Information Service, 5285 Port Royal Road, Springfield, VA 22161, phone: (800) 553-6847, fax: (703) 605-6900

email: orders@ntis.fedworld.gov

online ordering: http://www.ntis.gov/help/index.asp

Available electronically at http://www.osti.gov/bridge

Available for a processing fee to U.S. Department of Energy and its contractors, in paper, from: U.S. Department of Energy, Office of Scientific and Technical Information, P.O. Box 62, Oak Ridge, TN 37831-0062,

phone: (865)576-8401,

fax: (865)576-5728

email: $\underline{\text { reports@ adonis.osti.gov }}$ 
WSRC-TR-2002-00450

\section{WASHING DEMONSTRATION USING NONRADIOACTIVE SIMULATED TANK 7 SLUDGE-SLURRY}

\section{SUMMARY}

Tank 7 will be processed as part of the next sludge batch (Sludge Batch $3^{*}$ ) in the Defense Waste Processing Facility (DWPF). Prior to processing in DWPF, a sludge-slurry must be washed to adjust the sodium content and weight percent total solids ${ }^{\dagger}$. In typical sludge slurries, sodium is primarily soluble and easily adjusted by diluting and decanting the supernate (i.e., washing). For Tank 7, sodium adjustment is complicated by the presence of sodium oxalate which is partially soluble in aqueous solutions. To better understand how sodium oxalate would affect sludge washing, nonradioactive simulated Tank 7 sludge-slurry was prepared and washed. Soluble species (e.g., nitrate) were easily removed as expected. Sodium oxalate behaved like a partially soluble compound. As sodium concentration in wash water decreased, oxalate concentration increased until the equilibrium concentrations for sodium and oxalate were reached. Thus, sludge-slurry washing, even in the presence of sodium oxalate, is predictable.

\section{INTRODUCTION}

Tank 7 will be processed as part of Sludge Batch $3^{*}$ ) in the DWPF. Prior to processing in DWPF, a sludge-slurry must be washed to adjust the sodium content and weight percent total solids $\dagger$. In typical sludge-slurries, sodium is primarily soluble and easily adjusted by diluting and decanting the supernate (i.e., washing). For Tank 7, sodium adjustment is complicated by the presence of sodium oxalate which is partially soluble in aqueous solutions. The presence of oxalate may also complicate glass processing (melter offgas, glass redox, etc.).

At the time of this work, the sodium and oxalate content in Sludge Batch 3 for DWPF processing were not defined. Therefore, the purpose of this work was to better understand how sodium, in the presence of oxalate, is washed from sludge slurry, and to provide input for washing the waste qualification sample in the Savannah River Technology Center (SRTC) Shielded Cells. To accomplish this purpose, two tests were conducted. The first was a small scale centrifuge tube test. Sludge slurry was washed, allowed to sit overnight, and then centrifuged to facilitate decanting. The second test was on a slightly larger scale. Also, instead of centrifuging, sludge was allowed to gravity settle prior to each decant. The purpose of this larger scale test was to identify any settling issues, especially as sodium supernate concentrations dropped below $0.5 \mathrm{M}$.

\footnotetext{
* Sludge Batch 3 for the Defense Waste Processing Facility will consist of the Sludge Batch 1B heel in Tank 51, $\mathrm{Am} / \mathrm{Cm}$ and $\mathrm{Pu} / \mathrm{Gd}$ slurries transferred from $\mathrm{F}$ and $\mathrm{H}$-Areas into Tank 51, and the sludge slurry in Tank 7 . However, the focus of this work is Tank 7 only; the other components of Sludge Batch 3 were not evaluated or considered.

${ }^{\dagger}$ Although weight percent total solids adjustment is an important aspect of washing, the scope of this work was sodium and oxalate adjustment/removal.
} 
WSRC-TR-2002-00450

\section{EXPERIMENTAL}

\section{Sludge-Slurry Preparation}

Nonradioactive simulated Tank 7 sludge-slurry was prepared from washed Tank 8 nonradioactive simulant used for Sludge Receipt and Adjustment Tank (SRAT) experiments ${ }^{1}$. The washed Tank 8 simulant was dewashed, and sodium oxalate, sand, and coal were added. See Appendix A for Tank 8 simulant composition and chemicals added to dewash the simulant.

\section{Washing the Tank 7 Dewashed Simulant}

Two separate sludge washing experiments were completed: a small scale ( $5 \mathrm{~g}$ of sludge-slurry) experiment utilizing a centrifuge prior to each decant, and a larger scale $(100 \mathrm{~mL}$ of sludgeslurry) experiment where the sludge was allowed to gravity settle. All tests were conducted at room temperature.

For the centrifuge tube washes, $5 \mathrm{~g}$ of sludge slurry were placed into a $10 \mathrm{~mL}$ glass centrifuge tube. The sludge-slurry was washed ten times. Each wash consisted of:

- $\quad$ an addition of $5 \mathrm{~g}$ of inhibited water

- mixing well

- allowing the mixture to settle overnight

- centrifuging to make decanting easier

- decanting approximately $5 \mathrm{~g}$ of supernate with a slurry pipette.

The decanted supernates were submitted to SRTC Analytical Development Section (ADS) and to the SRTC Mobile Lab for cation analysis by Inductively Coupled Plasma-Emission Spectroscopy (ICP-ES) and anion analysis by Ion Chromatography (IC).

For the larger scale washes, $100 \mathrm{~mL}$ of sludge slurry were placed into a $250 \mathrm{~mL}$ polycarbonate bottle. The sludge-slurry was washed ten times. Each wash consisted of

- an addition of $100 \mathrm{~mL}$ of inhibited watert

- mixing well

- allowing the sludge to settle for at least two days to allow decanting of $100 \mathrm{~mL}$ supernate

- decanting approximately $100 \mathrm{~mL}$ of supernate with a slurry pipette.

The densities of the decanted supernates were measured using a $2 \mathrm{~mL}$ (nominal) Gay-Lussac bottle. The supernates were then submitted to SRTC-ADS for cation analysis by ICP-ES and anion analysis by IC.

\footnotetext{
* The inhibited water had a sodium concentration of $0.03 \mathrm{M}$, nitrite concentration of $0.015 \mathrm{M}$, and hydroxide concentration of $0.015 \mathrm{M}$.
} 
WSRC-TR-2002-00450

\section{RESULTS}

Table 1 and Table 2 summarize the sludge-slurry washing results. Each table shows the concentrations of the major components of each wash water (decant). A more detailed table showing additional components and quantities of inhibited water added and supernate decanted for the gravity settling tests is given in Appendix B.

Table 1. Centrifuge Tube Wash Results

Tube 12

\begin{tabular}{lcccc}
$\begin{array}{l}\text { Wash } \\
\text { No. }\end{array}$ & $\begin{array}{c}\text { Sodium } \\
(\mathrm{M})\end{array}$ & $\begin{array}{c}\text { Nitrite } \\
(\mathrm{M})\end{array}$ & $\begin{array}{c}\text { Nitrate } \\
(\mathrm{M})\end{array}$ & $\begin{array}{c}\text { Oxalate } \\
(\mathrm{M})\end{array}$ \\
\hline 1 & 1.85 & 0.77 & 0.086 & 0.043 \\
2 & 0.98 & 0.28 & 0.030 & 0.101 \\
3 & 0.68 & 0.13 & 0.011 & 0.16 \\
4 & 0.58 & 0.06 & 0.0044 & 0.21 \\
5 & 0.56 & 0.033 & 0.0019 & 0.22 \\
6 & 0.58 & 0.022 & $<0.0016$ & 0.20 \\
7 & 0.54 & 0.022 & $<0.0016$ & 0.20 \\
8 & 0.52 & 0.018 & $<0.0016$ & 0.21 \\
9 & 0.28 & 0.017 & $<0.0016$ & 0.12 \\
10 & 0.13 & 0.018 & $<0.0016$ & 0.06
\end{tabular}

Tube 14

\begin{tabular}{cccc}
\hline $\begin{array}{c}\text { Sodium } \\
(\mathrm{M})\end{array}$ & $\begin{array}{c}\text { Nitrite } \\
(\mathrm{M})\end{array}$ & $\begin{array}{c}\text { Nitrate } \\
(\mathrm{M})\end{array}$ & $\begin{array}{c}\text { Oxalate } \\
(\mathrm{M})\end{array}$ \\
\hline 1.90 & 0.79 & 0.086 & 0.037 \\
0.83 & 0.26 & 0.030 & 0.095 \\
0.61 & 0.13 & 0.013 & 0.17 \\
0.51 & 0.06 & 0.0054 & 0.21 \\
0.48 & 0.036 & 0.0023 & 0.22 \\
0.55 & 0.025 & $<0.0016$ & 0.20 \\
0.52 & 0.022 & $<0.0016$ & 0.20 \\
0.53 & 0.019 & $<0.0016$ & 0.21 \\
0.40 & 0.019 & $<0.0016$ & 0.14 \\
0.15 & 0.017 & $<0.0016$ & 0.06
\end{tabular}

Table 2. Gravity Settling Wash Results

Vessel A

\begin{tabular}{lcccc}
$\begin{array}{l}\text { Wash } \\
\text { No. }\end{array}$ & $\begin{array}{c}\text { Sodium } \\
(\mathrm{M})\end{array}$ & $\begin{array}{c}\text { Nitrite } \\
(\mathrm{M})\end{array}$ & $\begin{array}{c}\text { Nitrate } \\
(\mathrm{M})\end{array}$ & $\begin{array}{c}\text { Oxalate } \\
(\mathrm{M})\end{array}$ \\
\hline $0^{\mathrm{a}}$ & 4.21 & 1.75 & 0.19 & 0.0064 \\
1 & 1.94 & 0.79 & 0.083 & 0.035 \\
2 & 1.12 & 0.38 & 0.043 & 0.074 \\
3 & 0.72 & 0.18 & 0.021 & 0.13 \\
4 & 0.62 & 0.10 & 0.0091 & 0.18 \\
5 & 0.54 & 0.054 & 0.0042 & 0.21 \\
6 & 0.53 & 0.033 & 0.0018 & 0.23 \\
7 & 0.51 & 0.023 & $<0.0016$ & 0.17 \\
8 & 0.50 & 0.018 & $<0.0016$ & 0.25 \\
9 & 0.39 & 0.016 & $<0.0016$ & 0.19 \\
10 & 0.24 & 0.015 & $<0.0016$ & 0.12
\end{tabular}

${ }^{a}$ Supernate composition prior to washing
Vessel B

\begin{tabular}{cccl}
\hline $\begin{array}{c}\text { Sodium } \\
(\mathrm{M})\end{array}$ & $\begin{array}{c}\text { Nitrite } \\
(\mathrm{M})\end{array}$ & $\begin{array}{c}\text { Nitrate } \\
(\mathrm{M})\end{array}$ & $\begin{array}{c}\text { Oxalate } \\
(\mathrm{M})\end{array}$ \\
\hline 4.21 & 1.75 & 0.19 & 0.0064 \\
1.89 & 0.79 & 0.084 & 0.037 \\
1.09 & 0.37 & 0.041 & 0.072 \\
0.73 & 0.18 & 0.021 & 0.13 \\
0.61 & 0.10 & 0.0096 & 0.18 \\
0.58 & 0.056 & 0.0044 & 0.20 \\
0.55 & 0.037 & 0.0021 & 0.24 \\
0.52 & 0.024 & $<0.0016$ & 0.25 \\
0.53 & 0.019 & $<0.0016$ & 0.25 \\
0.43 & 0.011 & $<0.0016$ & 0.19 \\
0.26 & 0.015 & $<0.0016$ & 0.12
\end{tabular}


WSRC-TR-2002-00450

\section{DISCUSSION}

Sludge-slurry washing is basically a diluting and dissolving process. Species soluble in the sludge-slurry supernate, such as nitrate, are diluted with wash water and removed by decanting the supernate. Partially soluble compounds, such as sodium oxalate, must dissolve into the wash water before removal. Dissolving of these compounds is limited by compound solubility. This is shown graphically in Figure 1 and Figure 2 as semi-log plots. For nitrate, the concentrations decrease linearly with each successive wash indicating that they follow the general serial dilution formula:

$$
\begin{gathered}
C_{x}=\frac{\mathrm{C}_{\mathrm{i}}}{\mathrm{D}^{x}} \\
\text { or, in } \log \text { form, } \\
\log C_{x}=-x \cdot \log \mathrm{D}+\log \mathrm{C}_{\mathrm{i}}
\end{gathered}
$$

where

$x=$ number of serial dilutions

$\mathrm{D}=$ dilution factor

$\mathrm{C}_{\mathrm{i}}=$ initial concentration of soluble component

$C_{x}=$ concentration of soluble component after x serial dilutions.

A curve fit of the nitrate results from the gravity settled tests yields:

$$
C_{x}=\frac{0.19}{2.1^{x}}, \mathrm{R}^{2}=0.999
$$

where 0.19 is the nitrate molarity prior to washing.

Nitrite initially follows the serial dilution formula. However, its concentration eventually approaches $0.015 \mathrm{M}$, as this is the nitrite concentration in the wash water. This is shown in Table 3. The serial dilution formula predicts fairly well the nitrite concentration for the first 4 washes. 


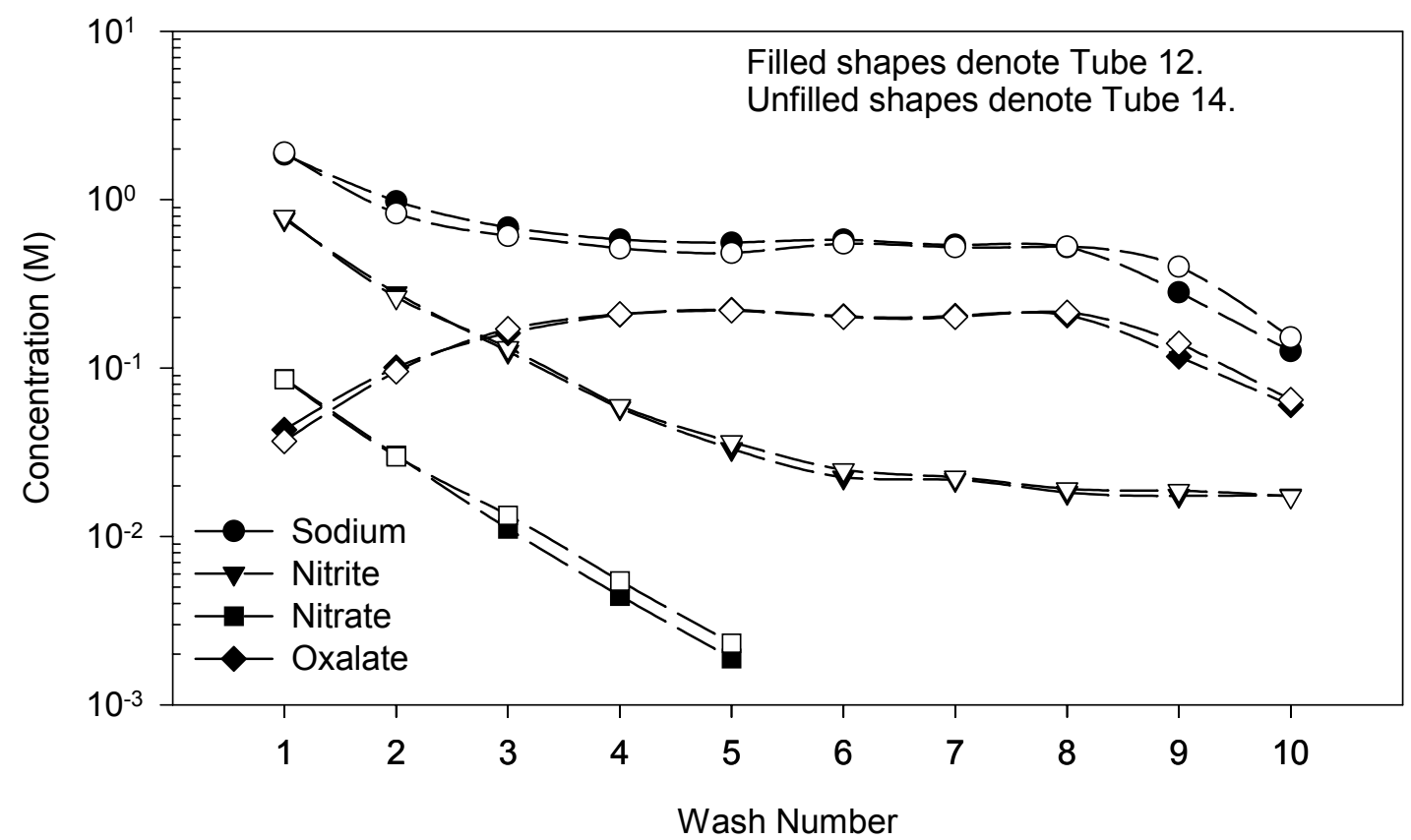

Figure 1. Supernate Concentration as a Function of Wash Number for Washing of Simulated Tank 7 Sludge-Slurry Utilizing a Centrifuge to Separate Sludge From Supernate

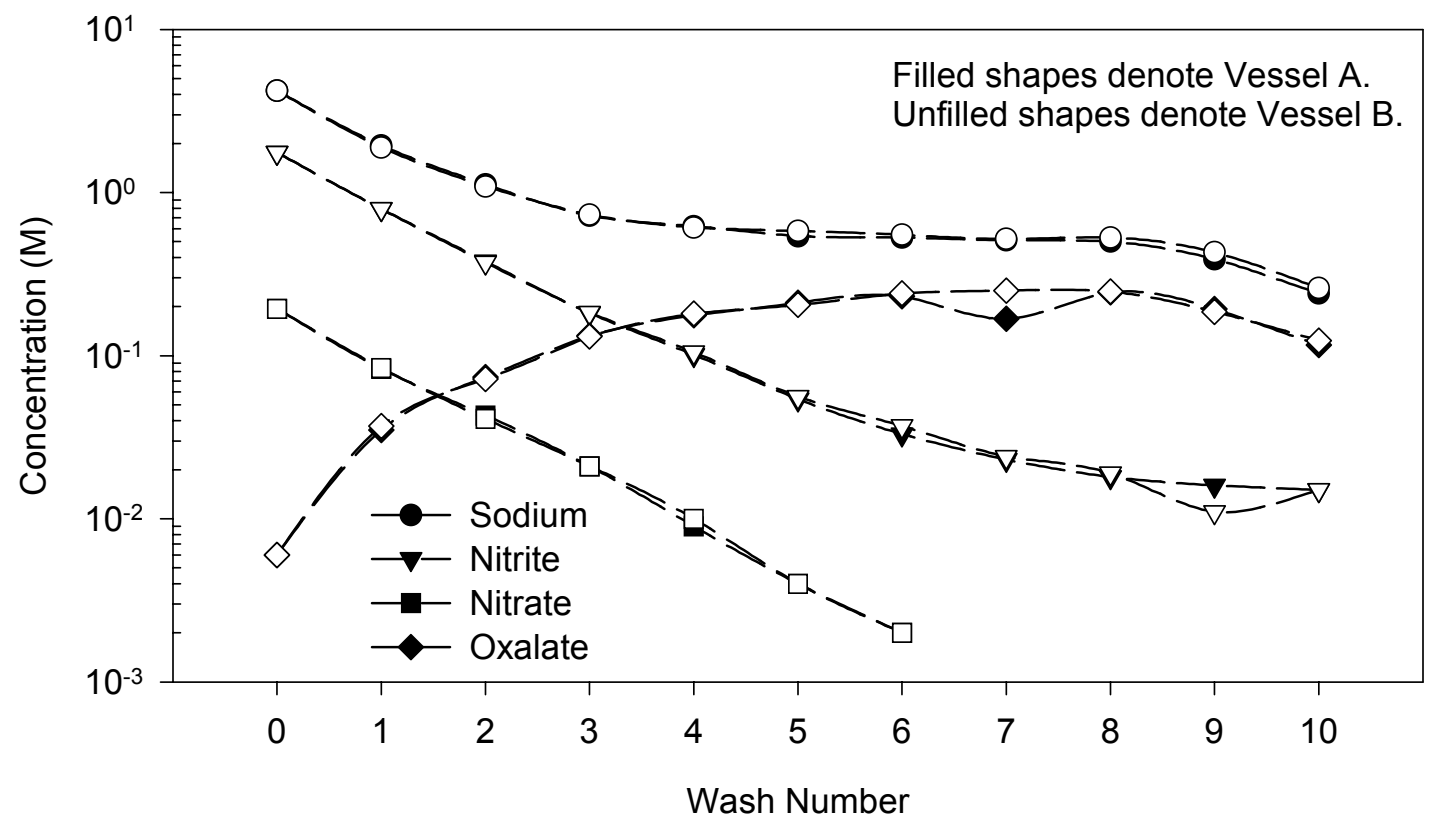

Figure 2. Supernate Concentration as a Function of Wash Number for Washing of Simulated Tank 7 Sludge-Slurry Allowing the Sludge to Gravity Settle 
WSRC-TR-2002-00450

Table 3. Comaparison of Measured and Predicted Nitrite concentraiton in the Gravity Settling Tests Using the Serial Dilution Equation

\begin{tabular}{lccc} 
Wash No. & $\begin{array}{c}\text { Predicted } \\
\text { Nitrite } \\
\text { Concentration } \\
(\mathrm{M})\end{array}$ & $\begin{array}{c}\text { Vessel A } \\
\text { Measured Nitrite } \\
\text { Concentration } \\
(\mathrm{M})\end{array}$ & $\begin{array}{c}\text { Vessel B } \\
\text { Measured Nitrite } \\
\text { Concentration } \\
(\mathrm{M})\end{array}$ \\
\hline 0 & 1.75 & 1.75 & 1.75 \\
1 & 0.83 & 0.79 & 0.79 \\
2 & 0.40 & 0.38 & 0.37 \\
3 & 0.19 & 0.18 & 0.18 \\
4 & 0.09 & 0.10 & 0.10 \\
5 & 0.043 & 0.054 & 0.056 \\
6 & 0.020 & 0.033 & 0.037 \\
7 & 0.010 & 0.023 & 0.024 \\
8 & 0.0046 & 0.018 & 0.019 \\
9 & 0.0022 & 0.016 & 0.011 \\
10 & 0.0010 & 0.015 & 0.015
\end{tabular}

The sodium concentration initially decreases, while oxalate concentration initially increases during washing. The concentrations then stabilize at approximately $0.5 \mathrm{M}$ sodium and $0.25 \mathrm{M}$ oxalate for several washes. These values are the published equilibrium concentrations for sodium oxalate in water at $20^{\circ} \mathrm{C}^{2}$. During these washes, sodium oxalate is dissolving up to its solubility limit. This shows that, in terms of equilibrium, sodium oxalate behaves as one would expect - increased sodium solution concentration decreases sodium oxalate solubility. An estimate of oxalate concentration can be made, given the sodium concentration using a calculated solubility product. The chemical equilibrium equation is:

$$
\mathrm{Na}_{2} \mathrm{C}_{2} \mathrm{O}_{4}(\mathrm{~s}) \leftrightarrow 2 \mathrm{Na}^{+}+\mathrm{C}_{2} \mathrm{O}_{4}{ }^{2-},
$$

with

$$
K_{s p}=\left[\mathrm{Na}^{+}\right]^{2} \cdot\left[\mathrm{C}_{2} \mathrm{O}_{4}{ }^{2-}\right] .
$$

Using the published equilibrium concentrations of $0.5 \mathrm{M}$ sodium and $0.25 \mathrm{M}$ oxalate, the calculated solubility product is 0.0625 . Given the measured sodium content and the calculated solubility product, the oxalate concentration was measured and compared to the analytical results. This comparison is shown in Table 4.

An examination of Table 4 shows that the oxalate prediction method underestimates oxalate concentration in the first few washes, and overestimates oxalate concentration in the last few washes. The primary reason for the underestimation is the solubility product used for these predictions was assumed to be constant regardless of solution ionic strength. Predictions would be improved if one used a more rigorous model that took into consideration the variation in solubility product as ionic strength changed. The oxalate concentration is over predicted in the last few washes due to the implicit assumption in the prediction that oxalate concentration is only dependant on sodium concentration. 
WSRC-TR-2002-00450

Table 4. Comparison of Measured and Predicted Oxalate Concentrations from the Gravity Settling Tests

\begin{tabular}{|c|c|c|c|c|c|c|}
\hline \multirow{3}{*}{$\begin{array}{l}\text { Wash } \\
\text { No. }\end{array}$} & \multicolumn{3}{|c|}{ Vessel A } & \multicolumn{3}{|c|}{ Vessel B } \\
\hline & Measured & Measured & Predicted & Measured & Measured & Predicted \\
\hline & Sodium (M) & Oxalate (M) & Oxalate (M) & Sodium (M) & Oxalate (M) & Oxalate (M) \\
\hline $0^{\mathrm{a}}$ & 4.21 & 0.0064 & 0.004 & 4.21 & 0.0064 & 0.004 \\
\hline 1 & 1.94 & 0.035 & 0.017 & 1.89 & 0.037 & 0.018 \\
\hline 2 & 1.12 & 0.074 & 0.050 & 1.09 & 0.072 & 0.053 \\
\hline 3 & 0.72 & 0.13 & 0.12 & 0.73 & 0.13 & 0.12 \\
\hline 4 & 0.62 & 0.18 & 0.16 & 0.61 & 0.18 & 0.17 \\
\hline 5 & 0.54 & 0.21 & 0.21 & 0.58 & 0.20 & 0.19 \\
\hline 6 & 0.53 & 0.23 & 0.22 & 0.55 & 0.24 & 0.21 \\
\hline 7 & 0.51 & 0.17 & 0.24 & 0.52 & 0.25 & 0.23 \\
\hline 8 & 0.50 & 0.25 & 0.25 & 0.53 & 0.25 & 0.23 \\
\hline 9 & 0.39 & 0.19 & 0.41 & 0.43 & 0.19 & 0.33 \\
\hline 10 & 0.24 & 0.12 & 1.12 & 0.26 & 0.12 & 0.96 \\
\hline
\end{tabular}

Knowing that sodium oxalate behaves as it should in sludge-slurry enables one to predict sodium oxalate removal during washing. Once sodium concentration is lowered to $0.5 \mathrm{M}$ (after 4 washes in these experiments), the amount of oxalate removed per wash is simply equal to the oxalate solubility concentration multiplied by the decant volume.

A plot of fraction of oxalate removed as a function of number of washes is illustrative. For these experiments, inhibited water additions and decants were nearly equal. Therefore, once sodium concentration drops to $0.5 \mathrm{M}$, the rate of oxalate removal should be constant. This is indeed the case, as shown in Figure 3 by a nearly straight line.

In comparing the centrifuge tube tests to the gravity settling tests, there were no significant differences. Also, there were no issues with sludge settling in these tests. Two days of settling were sufficient to allow for easy decants. 
WSRC-TR-2002-00450

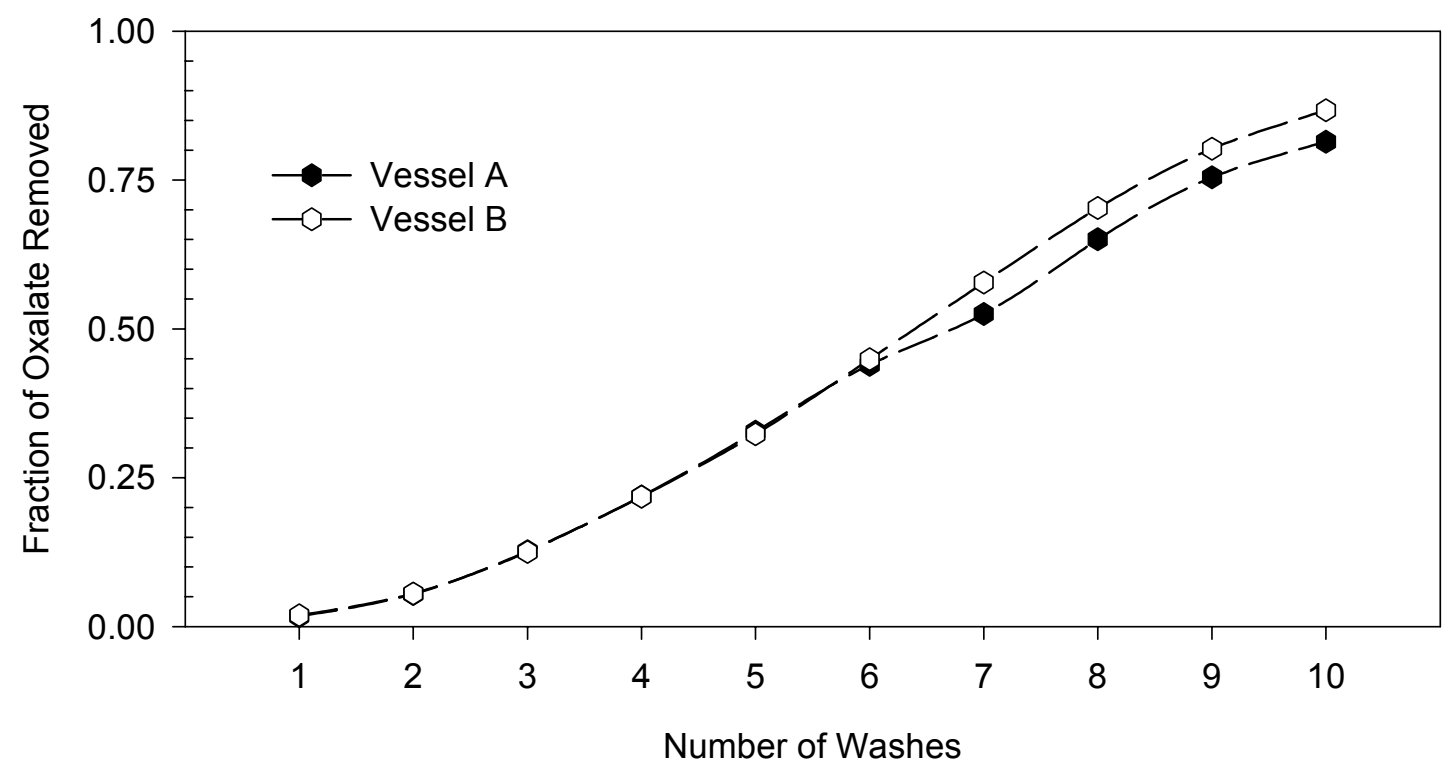

Figure 3. Fraction of Oxalate Removed as a Function of Number of Washes for Washing of Simulated Tank 7 Sludge-Slurry Allowing the Sludge to Gravity Settle

\section{CONCLUSIONS}

Washing of soluble species and sodium oxalate from simulated Tank 7 sludge-slurry is predictable. For example, soluble species such as nitrate and nitrite are washed from the sludgeslurry following a serial dilution equation, while sodium oxalate removal can be predicted based on published sodium oxalate solubility in aqueous solutions. Although the composition of Sludge Batch 3 will inevitably be different than the nonradioactive simulated Tank 7 sludgeslurry, this work gives confidence that a washing strategy for the next sludge batch can be developed. 
WSRC-TR-2002-00450

\section{APPENDIX A - SIMULATED TANK 7 SLUDGE-SLURRY PREPARATION}

The starting material for simulated Tank 7 sludge-slurry was washed simulated Tank 8 sludgeslurry. The elemental composition of this Tank 8 simulant is given in Table A-1 ${ }^{3}$.

Table A-1. Elemental Composition of Washed Simulated Tank 8 Sludge-Slurry

\begin{tabular}{cc} 
Element & Wt. \% Total Solids \\
\hline $\mathrm{Al}$ & 9.30 \\
$\mathrm{Ba}$ & 0.20 \\
$\mathrm{Ca}$ & 2.22 \\
$\mathrm{Cr}$ & 0.22 \\
$\mathrm{Cu}$ & 0.13 \\
$\mathrm{Fe}$ & 26.2 \\
$\mathrm{~K}$ & 0.01 \\
$\mathrm{Mg}$ & 0.12 \\
$\mathrm{Mn}$ & 2.55 \\
$\mathrm{Na}$ & 6.0 \\
$\mathrm{Ni}$ & 2.81 \\
$\mathrm{~Pb}$ & 0.10 \\
$\mathrm{Si}$ & 0.89 \\
$\mathrm{Sr}$ & 0.08 \\
$\mathrm{Zn}$ & 0.22 \\
$\mathrm{Zr}$ & 0.37
\end{tabular}

The Tank 8 simulant was dewashed by adding $\mathrm{Na}_{2} \mathrm{CO}_{3}, \mathrm{NaCl}, \mathrm{NaOH}, \mathrm{NaNO}_{2}, \mathrm{NaNO}_{3}$, and $\mathrm{Na}_{2} \mathrm{SO}_{4}$. Finally, sodium oxalate, coal, and sand were added to simulate Tank 7 sludge-slurry. The amount of sodium oxalate to add was based on the proposed ratio of 300,000 $\mathrm{kg}$ sodium oxalate to $413,000 \mathrm{~kg}$ total solids (excluding sodium oxalate) in Tank 7. This translates to $0.24 \mathrm{~g}$ of sodium oxalate per $\mathrm{g}$ of dewashed simulated Tank 8 sludge-slurry ( $w t \%$ total solids $=33$ ). 


\section{APPENDIX B - DETAILED SLUDGE-SLURRY WASHING RESULTS FOR THE GRAVITY SETTLING EXPERIMENTS}

Vessel A Sludge-Slurry Mass $132.423 \mathrm{~g}$

Vessel B Sludge-Slurry Mass 131.482 g

\begin{tabular}{|c|c|c|c|c|c|c|c|c|c|}
\hline \multirow[b]{2}{*}{$\begin{array}{l}\text { Wash } \\
\text { No }\end{array}$} & \multirow{2}{*}{$\begin{array}{l}\text { Inhibited } \\
\text { Water } \\
\text { Added } \\
\text { (g) }\end{array}$} & \multirow[b]{2}{*}{$\begin{array}{l}\text { Supernate } \\
\text { Decanted } \\
\text { (g) }\end{array}$} & \multirow[b]{2}{*}{$\begin{array}{c}\text { Decant } \\
\text { Density } \\
\text { (mg/L) }\end{array}$} & \multicolumn{6}{|c|}{ Concentration in Decanted Supernate } \\
\hline & & & & $\begin{array}{c}\mathrm{Na} \\
(\mathrm{mg} / \mathrm{L})\end{array}$ & $\begin{array}{c}\mathrm{Al} \\
(\mathrm{mg} / \mathrm{L})\end{array}$ & $\begin{array}{c}\mathrm{Ca} \\
(\mathrm{mg} / \mathrm{L})\end{array}$ & $\begin{array}{c}\mathrm{NO}_{2}^{-} \\
(\mathrm{mg} / \mathrm{L})\end{array}$ & $\begin{array}{c}\mathrm{NO}_{3}^{-} \\
(\mathrm{mg} / \mathrm{L})\end{array}$ & $\begin{array}{l}\mathrm{C}_{2} \mathrm{O}_{4}{ }^{2-} \\
(\mathrm{mg} / \mathrm{L})\end{array}$ \\
\hline \multicolumn{10}{|c|}{ Vessel A } \\
\hline 0 & 0 & 0 & $1.19^{a}$ & 96900 & NM & NM & 80700 & 12000 & 567 \\
\hline 1 & 109.61 & 107.374 & 1.10 & 44600 & 3070 & 2.69 & 36500 & 5130 & 3050 \\
\hline 2 & 100.013 & 102.551 & 1.04 & 25700 & 1760 & 2.35 & 17400 & 2640 & 6500 \\
\hline 3 & 101.393 & 108.508 & 1.03 & 16600 & 938 & 0.99 & 8360 & 1290 & 11700 \\
\hline 4 & 97.756 & 102.422 & 1.01 & 14300 & 517 & 1.77 & 4630 & 566 & 15600 \\
\hline 5 & 100.114 & 102.353 & 1.02 & 12500 & 299 & 1.02 & 2470 & 259 & 18600 \\
\hline 6 & 100.116 & 96.843 & 1.02 & 12300 & 211 & 0.80 & 1520 & 114 & 20300 \\
\hline 7 & 99.005 & 101.701 & 1.03 & 11700 & 148 & 0.75 & 1080 & $<100$ & 14800 \\
\hline 8 & 100.066 & 101.646 & 1.02 & 11600 & 114 & 0.74 & 848 & $<100$ & 21600 \\
\hline 9 & 100.212 & 106.33 & 1.01 & 9050 & 96.8 & 0.47 & 754 & $<100$ & 17000 \\
\hline 10 & 98.933 & 102.223 & 1.02 & 5440 & 87.2 & 0.26 & 708 & $<100$ & 10200 \\
\hline \multicolumn{10}{|c|}{ Vessel B } \\
\hline 0 & 0 & 0 & $1.19^{a}$ & 96900 & NM & NM & 80700 & 12000 & 567 \\
\hline 1 & 105.727 & 108.282 & 1.081 & 43400 & 2980 & 2.67 & 36400 & 5180 & 3240 \\
\hline 2 & 100.013 & 102.073 & 1.047 & 25000 & 1740 & 2.52 & 17100 & 2550 & 6360 \\
\hline 3 & 100.242 & 107.512 & 1.040 & 16700 & 954 & 0.99 & 8440 & 1300 & 11500 \\
\hline 4 & 98.391 & 101.769 & 1.026 & 14000 & 538 & 1.08 & 4810 & 594 & 15900 \\
\hline 5 & 100.039 & 102.236 & 1.032 & 13400 & 313 & 1.10 & 2560 & 272 & 18000 \\
\hline 6 & 100.219 & 102.871 & 1.019 & 12600 & 217 & 0.75 & 1690 & 132 & 21200 \\
\hline 7 & 99.108 & 101.416 & 1.022 & 12000 & 153 & 0.78 & 1120 & $<100$ & 22100 \\
\hline 8 & 100.065 & 100.936 & 1.030 & 12100 & 118 & 0.75 & 881 & $<100$ & 21700 \\
\hline 9 & 100.499 & 105.307 & 1.018 & 10000 & 99.2 & 0.51 & 517 & $<100$ & 16400 \\
\hline 10 & 98.263 & 101.267 & 1.005 & 5890 & 87.7 & 0.26 & 696 & $<100$ & 10900 \\
\hline
\end{tabular}

NM - not measured

${ }^{\mathrm{a}}$ Supernate density 
WSRC-TR-2002-00450

\section{REFERENCES}

1. Poirier, M. R. Specification for Procurement of Tank 40 and Tank 8 Sludge Feed Simulants. SRT-WHM-2000-004, Rev. 2, Savannah River Site, Aiken, SC 29808 (2000).

2. Lide, D. R., ed. CRC Handbook of Chemistry and Physics. 79th ed., CRC Press, Boca Raton, FL (1998).

3. Fellinger, T. L., et.al. Demonstration of the Tank Farm Washing Process and the DWPF SRAT Cycle with Sludge Batch 3 Simulant and Precipitated Pu/Gd Mixture from H-Canyon Tank 18.3(U). WSRC-TR-2002-00208, Savannah River Site, Aiken, SC 29808 (2002). 